\title{
ICT PERSONNEL MATURITY TOWARDS GREEN ICT IN KENYA
}

\author{
${ }^{1}$ Dr. Franklin Wabwoba, ${ }^{2}$ Dr. Samuel Mbugua, ${ }^{3}$ Mr. Anselemo Peters Ikoha, ${ }^{4} \mathrm{Ms}$. Dorcus \\ Arshley Shisoka
}

\author{
School of Computing and Informatics, Kibabii University College \\ P.O. Box 1699-50200, Bungoma \\ Kenya
}

\begin{abstract}
Though ICT is contributing to the economy associated with innovations, inventions and rapid development in almost all aspects of human life, is responsible for climatic degradation. The rapid increase of ICT usage means more costs of doing business, energy consumption, and more environmental challenges. The rapid changing technology reaching Kenya and lack of their understanding has put a lot of pressure on both management and ICT personnel to implement them on a trial and error manner. This has limited the gains meant to be obtained from green ICT despite its technologies availability. The lack of ICT personnel capacity readiness challenges the reaping of green ICT benefits. The study was informed by the G-readiness model and the enhanced G-readiness model. This study purposed to determine the personnel capacities readiness towards green ICT in Kenya. The study was undertaken using the interpretive, inductive multi-case survey study on a population of four data centres and 116 ICT managerial, technical and user personnel that were purposively sampled. Interview, observation, questionnaire and document analysis methods were used to gather data that was triangulated to increase the reliability and validity. The study established the ICT personnel's G-readiness was very low on both training and professional development perspectives in Kenya. The study's findings are useful towards the strategic planning for green ICT implementation, cutting down running costs, improving environmental performance of organisations and contribution to the world of knowledge. The findings provide data for informed ICT personnel and workplace readiness alignment, decision making and ICT curriculum development. The study recommends application of green ICT based on established ICT personnel capacity, inclusion of green ICT training in the curriculum, creation of green ICT responsibilities, provision for a green ICT budget and investment into the development of green ICT personnel.
\end{abstract}

\section{Indexing terms/Keywords}

G-ICT personnel readiness, green ICT, Kenya.

\section{Academic Discipline And Sub-Disciplines}

Provide examples of relevant academic disciplines for this journal: E.g., History; Education; Sociology; Psychology; Cultural Studies;

\section{SUBJECT CLASSIFICATION}

Information Technology

\section{TYPE (METHOD/APPROACH)}

Survey/Interview

\section{Council for Innovative Research}

Peer Review Research Publishing System

Journal: INTERNATIONAL JOURNAL OF COMPUTERS \& TECHNOLOGY

Vol 13, No. 3

editor@cirworld.com

www.cirworld.org/journals, www.ijctonline.com 


\subsection{Introduction}

Human capital is critical to implementations of Green Information and Communication Technology (G-ICT). Such personnel need to have experience, competency, commitment, values and norms of ICT consumers [1]. ICT personnel are employees who ensure that the technical infrastructure operates seamlessly and who design and run systems that support the business on the whole [2]; [3]. The perceived managerial capability for green ICT for sustainable ICT driven society entails the management of all ICT activities [4]. It is ICT managerial capability that ensures the alignment of IT support in the organization and its core competencies appropriately [5]. This is normally visualised through the kind of policies in place. The attitudes and actions of the ICT personnel and managerial capability greatly influence the choices made towards green ICT.

The level of implementation of green ICT is also influenced by the work place preparedness [6]. If the work place is ready for green ICT then there are high chances of the implementation being undertaken very fast. The preparedness within the organisation according to Molla et al, (2008) [4] is determined by attitudes, policies, practice, governance and technology of the given organisation. However, how well these elements are set in place is greatly influenced by the ICT personnel's readiness maturity. The implementation is influenced by the ICT personnel in the organisation who at the same time have some influence on the work place preparedness for green ICT. The personnel responsiveness to green ICT is however moderated by technical skills they possess. How well equipped, skilled and how frequently the ICT personnel upgrade their skills towards the same has a big impact on how they respond to needs for the implementation.

\subsection{ICT personnel}

Skilled and qualified human personnel are an inherent part of ICT and serve as a key to development [7]. This is even more critical for green ICT. However, there is a deficiency in not only green ICT personnel but in the whole ICT field globally and especially in developing nations [6]; [7]. It is these human personnel that determine the level of spread of technology. The occupations of ICT personnel being so diverse and not limited to the ones performed in the industry alone [7] pose a challenge to them in implementing green ICT. They go beyond planning, production, sale and maintenance of hardware and software equipment. Another challenge to the ICT personnel is the rapid rate at which technology is changing [6]; [7] putting pressure on them to upgrade their skills in order to cope with the emerging technologies.

\subsubsection{ICT personnel capacities}

For organizations ICT departments to be able to successfully discharge green ICT responsibility, the skills of the personnel working in the departments need to be fused together with the principles and issues of sustainability. Traditionally, highly specialised IT personnel are needed to solve complex problems. However, in the context of climate change, IT personnel need additional knowledge to cope with changing demands from the business side [8]. Knowledge about environmental sustainability is needed not only to manage ICT's own contribution to environmental problems but also position it as a key enabler of environmental sustainability.

Personnel skills status is critical to uptake and expansion of technologies and innovations. Qualified and appropriately skilled personnel are needed. That is the knowledge, skills, abilities and capacities to develop and innovate that is possessed by people in an organisation [9]. They also need to be readily available and in adequate numbers to propel green ICT With the rapidly changing ICT, the personnel will likewise need to frequently have their skills upgraded [6]. The quality of the training programs therefore towards the ICT personnel play a role in realising personnel readiness maturity.

Green ICT skilled personnel availability has an impact on how it is best implemented. Skilled and qualified human personnel are important to the development and utilisation of technology [10]. Naturally it is the humans and not machines who advance and control the spread of a technology [7]. However, ICT personnel are in short supply [6]. This becomes a critical factor therefore in planning for green ICT implementation within any country.

In a study by [11] it was found out that people will support adoption and hence implementation of emerging technologies for as long as the technologies are well understood. According to Info-Tech (2008) [12] lack of appropriate skills disempowers IT staff in the implementation and use of emerging technologies. Lack of technical skills can significantly hinder implementation of any given technology [13]; [14]; [15] and lead to failure of innovations implementation [16]. Lack of awareness can hinder technology implementation [17]. Awareness within technologies implementation can only be instituted in people and not in hardware or software. It is the people who are aware that determine the spread of technologies and not the hardware. When people are not aware of any given technology they develop resistance to implementing it [13]; [14]. Such resistance can easily lead to development of negative attitude towards green ICT and when shared out especially by ICT personnel may result in an organisation culture not being supportive of it [18].

\subsection{Statement of research problem}

The rapid changing technologies that are reaching the developing nations are likely to make the ICT utility values, effectiveness and efficiency not to be realised as ICT personnel implements them on a trial and error basis [19]. Many firms are heavily dependent on imported technology with skills adaptation to local needs receiving little attention. This has led to rise in costs, dematerialisation of resources and environmental degradation [20]. The ICT personnel capacity readiness is much more challenging to developing nations than developed nations as it has to deal with the rapid changing technologies coming on board as well the obsolete donations in the strive to become ICT driven nations. Green ICT has been widely promoted as an important strategy to reduce energy, materials consumption, and environmental degradation leading to sustainability [21]. Green hardware and software are readily available in the market to reduce energy and materials consumption [13]. However, this has not happened. ICT personnel preparedness contributes directly to how an 
organisation gets ready in terms of green ICT readiness [6]. It is therefore crucial in the reaping of green ICT benefits. Technology in itself does not determine how it can be successfully applied, the ICT personnel does. Green ICTs successful implementation is therefore, dependent on ICT personnel's readiness maturity. The question therefore is "What is their readiness maturity level in Kenya?

\subsection{Study objectives}

(i) To establish the G-ICT personnel training maturity in Kenya

(ii) To determine the level G-ICT professional development maturity in Kenya

(iii)To propose the way forward towards G-ICT personnel maturity in Kenya

\section{2 The knowledge gaps}

From the literature available in publications, the aspect of personnel remains a major gap in establishing workplace Greadiness. From the G-readiness model proposed by Molla et al (2008) [4] on which most green ICT studies have been based, it appears as if ICT personnel capacity has minimal influence on the way any given workplace would be set for technology implementation. Personnel capabilities vary greatly across nations and even organisations. The studies therefore have assumed ICT personnel capacity to be the same the whole world round.

It is the human who determine the level of spread of a technological innovation and not the innovation itself. Skilled personnel in the given area play a critical role as well as unskilled more so if they are aware of the technology. According to Niringiye, Luvanda \& Shitundu (2010) [22] and Iranzo, Schivardi, \& Tosetti (2008) [23], skilled labour is critical to increasing organisations' efficiency in the use of technology to realise increased productivity. ICT skill deficiency has been established to restrict adoption and implementation of technological innovations which strengthens the role of human capital in green ICT implementation.

Human capital has capabilities that are very hard to imitate. Human capital consists of the individuals' capabilities knowledge, skills and experiences [24]. Human capabilities are nurtured from three perspectives of the human, social and organisational. The human perspective has the knowledge, skills and abilities while the social perspective has the valuable relationships among the people, and the organisational perspective consists of the processes and routines within a firm [25]. The previous major studies on green ICT (G-readiness model, sustainable Information and Communication Technology and the absorptive capacity perspective model) have taken good consideration of the social and organisation perspective in establishing the green ICT readiness however, they pay little attention to human capital. The human perspective has influence on readiness of any given organisation as well. Generally the role played by the different types of ICT personnel readiness maturity towards technology adoption and implementation is often ignored in a number of studies dealing with technology which may explain the failures in information technology implementations.

Even though technology has improved over the last 30 years, there are still many examples of failed information technology implementations. One area that is important in technology implementation has got to do with personnel and is related to managing change to ensure its acceptance. This often is associated with education and training amongst other aspects that contribute towards the personnel capacity that has been studied minimally.

\subsection{Methodology}

The study surveyed four cases that included a leading sugar manufacturing factory in the country that has invested into intensive application of ICT in virtually all its operations, a university that offers training programs in Information and Communication Technology starting from certificate all the way to doctoral level, a communications commission involved in the regulatory tasks of Information and Communications Technology in the country and senior government officers. From the four cases respondents were selected based on the involvement in ICT use. They consisted of top management, ICT technical users, postgraduate (MSc and PhD) level students and senior government officers. The postgraduate students consisted of a combination of information and communication technology lecturers, ICT managers and ICT technical staff works in various companies and government departments in the country. The study used a combination of questionnaire, interview and observation to collect data. This was complimented with secondary data from literature.

\subsection{Discussion of findings on ICT personnel G-readiness preparedness maturity}

ICT personnel G-readiness establishes how well prepared the personnel are for green ICT adoption and implementation. This dimension is a new concept on G-readiness assessment model proposed by Molla et al (2009) [3] and suggested for its inclusion on the model by Wabwoba et al (2013) [6]. Personnel G-readiness is assessed in two main perspectives:-

(i) G-ICT personnel training maturity and

(ii) G-ICT personnel professional development [6].

\subsection{G-ICT personnel training maturity}

Personnel training maturity assesses the training, experience, gender and experience of the ICT personnel. The analyses of the findings are presented graphically in Figure 1. 


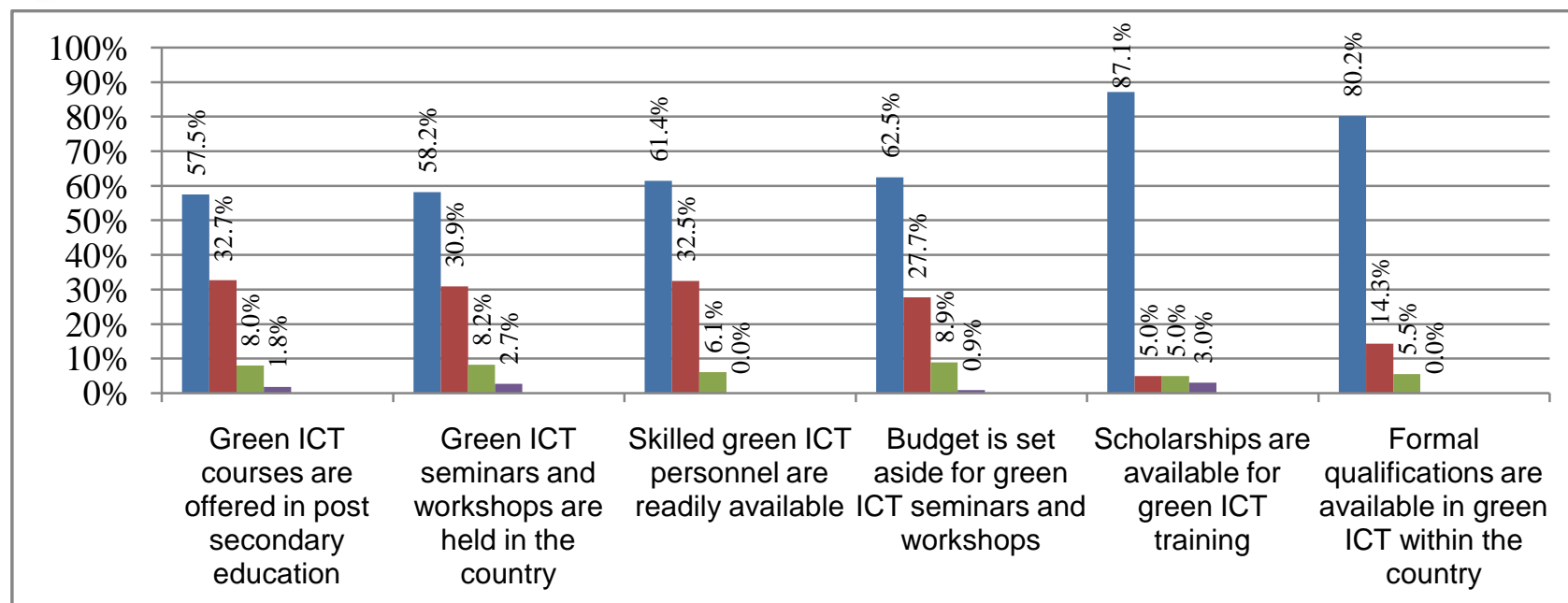

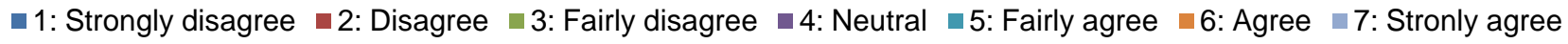

\section{Figure 1: ICT personnel maturity: Training}

The findings with regard to green ICT courses offered to personnel at post secondary school training were as presented in Figure 1 column 1 . Accordingly a total of $57.5 \%$ of the respondents strongly disagreed to having had any formal training on green ICT within their post secondary school ICT training. Another $32.7 \%$ disagreed while $8.0 \%$ fairly disagreed to the same. But $1.8 \%$ of the respondents were neutral in their response. This finding correlates with what was observed in the curriculum for training at the public university where not even a single course had a title of green ICT. The ICT personnel interviewed did indicate that they had never had any training on green ICT. The analysis of green ICT courses are offered in postsecondary ICT education programs resulted in the manufacturing sector having a mean of 1.25 , the communications regulator a mean of 1.73 while the public university sector had a mean of 1.57 and the government office had 1.67 .

Training may be within the institutions or through workshops and seminars. The findings on green ICT workshop or seminars held within the country are presented in Figure 1 column 2 . A total of $58.2 \%$ of the respondents strongly disagreed and $30.9 \%$ disagreed that the country had green ICT workshops and seminars while $8.2 \%$ fairly disagreed. At least $2.7 \%$ were neutral in their response to the country having green ICT workshops and seminars. From the findings it is clear that there are hardly any workshops or seminars in the country on green ICT. The analysis findings were similar to the findings obtained from observation of documents that yielded only a single green ICT seminars and workshops call within the country. The interviews conducted also gave similar results as hardly any of the respondents indicated to have attended green ICT seminars and workshops within the country. The manufacturing sector had a mean of 1.54 , the communications regulator had a mean of 1.40 while the public university sector had a mean of 1.67. However, government office had 1.50 for green ICT seminars / workshops in the held country.

Alongside the training, workshops and seminars, there is a need to have skilled personnel. Skilled personnel aside from implementing green ICT can be handy in organizing workshops and seminars as well as sharing out their experiences. The findings on how readily available skilled green ICT personnel were is presented in Figure 1 . From column $3,61.4 \%$ of the respondents strongly disagreed that green ICT personnel are readily available. Another $32.5 \%$ disagreed while $6.1 \%$ fairly disagreed to the same. The findings are in agreement with other findings that have established that ICT personnel are not on the overall available in developing economies.

Findings on whether a budget was set aside for attending green ICT seminars or workshops are presented in Figure 1. Based on the findings on column 4, 62.5\% of the respondents strongly disagreed that budget was set aside for attending green ICT seminars or workshops. Another $27.7 \%$ disagreed while $8.9 \%$ fairly disagreed to the same. At least $0.9 \%$ of respondents were neutral in their response as to whether the organisations had a budget set aside for attending green ICT seminars or workshops. According to the analysis, the mean value of budget provision for employees to attend green ICT seminars / workshops was 1.5. The ICT personnel interviewed stated that they had never heard about budgetary provision to enable them attend green ICT seminars or workshop. Equally there were no records availed to show that any organisation having sponsored an employee to attend a green ICT seminar or workshop. It is worth noting that this may be the case due to lack of such seminars and workshops locally. The means obtained with regard to budget being set aside for employees to attend green ICT seminars / workshops in the manufacturing sector had a mean of 1.57 , the communications regulator had a mean of 1.30 while the public university sector had a mean of 1.57 and the government office had 1.33 .

Provision of scholarships to train green ICT personnel is one of the many means for training green ICT personnel that are readily available. The findings on provision of scholarships are given in Figure 1 . According to column 5 a total of $87.1 \%$ of the respondents strongly disagreed that scholarships are available for green ICT training. Another $5.0 \%$ disagreed that scholarships are available for green ICT training while $5.0 \%$ fairly disagreed to the same. At least $3.0 \%$ of respondents 
were neutral in their response as to whether there scholarships are available for green ICT training. Unskilled personnel are likely to implement ICT on a trial and error basis that may lead to un-sustainability. This finding correlates with what was observed in the organisations as they hardly provided any records of personnel who had been sponsored to study / train in green ICT. The ICT personnel interviewed were clear about not knowing any person who had gotten a scholarship to train or study green ICT as a program. The manufacturing sector had a mean of 1.04 on scholarships availability for green ICT training, the communications regulator had a mean of 1.27 while the public university sector had a mean of 1.31 and the government office had 1.36 .

Scholarships to study lead to personnel acquiring formal qualifications. The findings on the availability of formal green ICT qualifications training in Kenya are presented in Figure 1. According to column 6 a total of $80.2 \%$ of the respondents strongly disagreed to the fact that there is formal training in green ICT available in Kenya. Another 14.32\% disagreed that there is formal training in green ICT available in Kenya while $5.5 \%$ fairly disagreed to the same. This strongly points to the fact that there may be no institution offering green ICT training which correlates with the finding that there are hardly any people possessing training in green ICT and probably the reason for the lower levels of the same. There is need to incooperate green ICT training in the curriculum.

Based on the analysis Figure 1, it can be observed that there are hardly any formal qualifications in green ICT. This is in correlation with the findings of observation of documents that did not show any person holding a formal qualification in green ICT. The interviews conducted also gave similar results as none of the respondents indicated to being aware of any person who held formal qualifications in green ICT. Finally on formal qualifications being available in green ICT in the country, the manufacturing sector had a mean of 1.09 , the communications regulator had a mean of 1.30 while the public university sector had a mean of 1.33 and the government office had a mean of 1.25.

According to the analysis Figure 1, the green ICT skilled personnel were hardly available in the ICT sector. It can be observed that availability of green ICT skilled personnel maturity was low and skewed to the left. A good number of the ICT personnel interviewed indicated they have not heard or do not know of any green ICT specialist within the country. Unfortunately this would not be confirmed with the national manpower data bank that is hardly there for ICT professionals. None of the organisations also confessed to have at any time employed a green ICT specialist.

The means of ICT personnel training G-readiness level in each particular case study was obtained to be as presented in Figure 2.

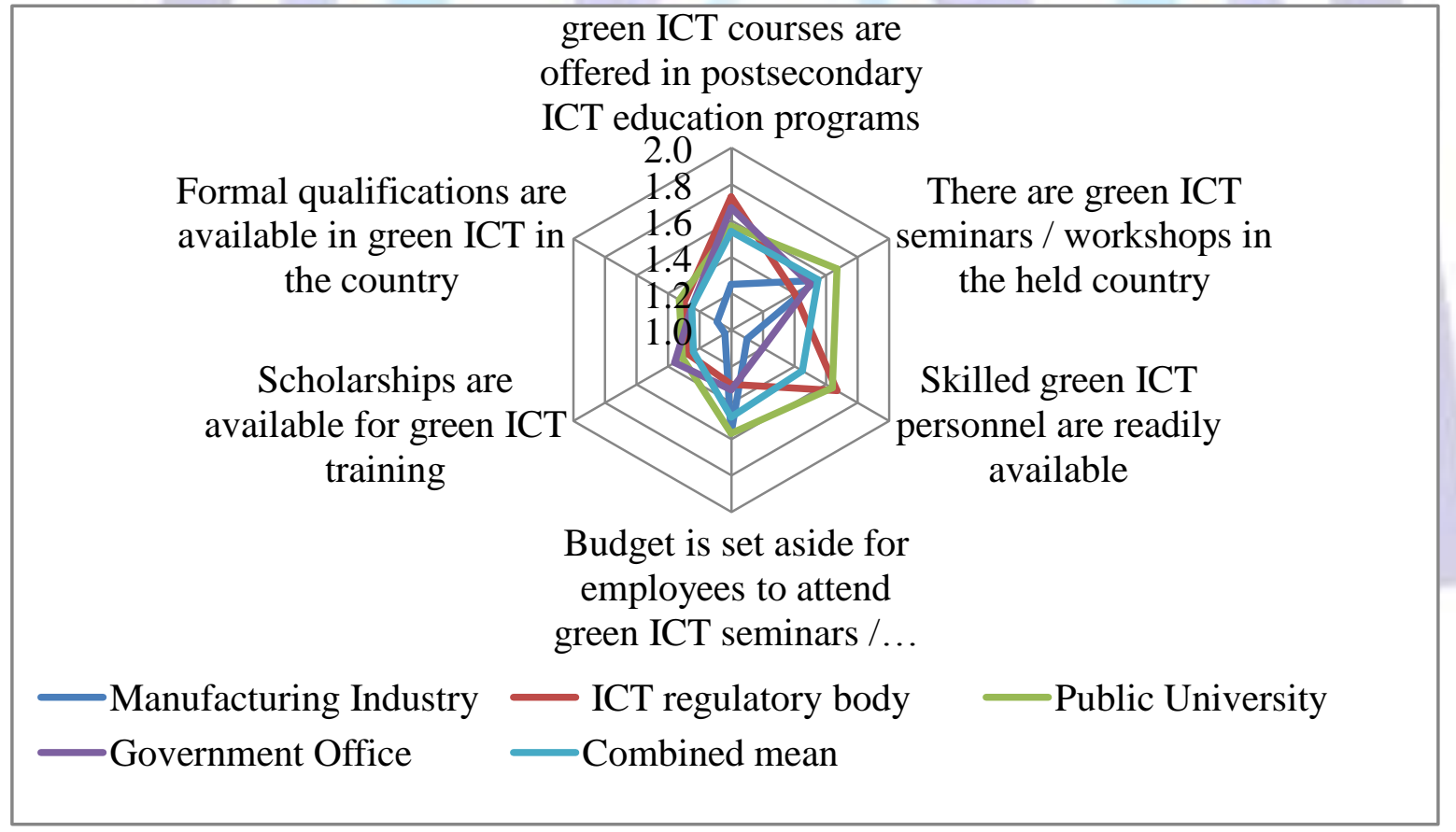

Figure 2: Case study comparison of green ICT training maturity

From Figure 2, it can be observed that the ICT personnel G-readiness is very low in all organisations as the curves hardly goes beyond 1.6 in any dimension on a scale of 7 . The curves are very close to 1 instead of being closer to 7 which is the indicator of high maturity. The public university sector however on the overall seems to be better off in maturity. This may be out of the influence of it being a training institution for the ICT personnel amongst other professions. Nevertheless ICT personnel readiness is the lowest all aspects of G-readiness. 


\subsection{G-ICT professional development maturity}

With reference to professional development the analysis is as presented in Figure 3.

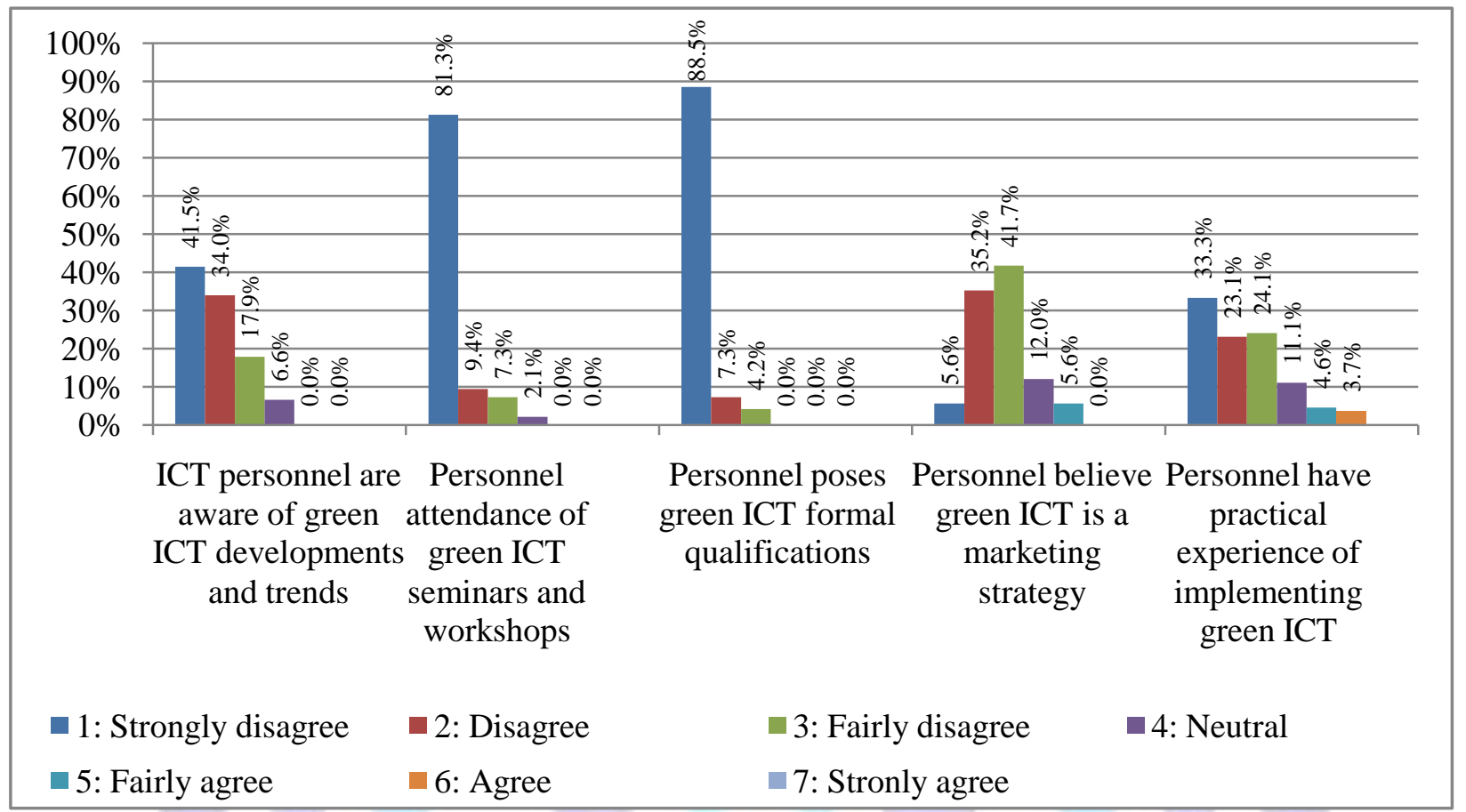

Figure 3: ICT personnel maturity: Professional development

The findings on the awareness of green ICT developments and trends are presented in Figure 3 . Based on the findings on column 1, a total of $41.5 \%$ of the respondents are not aware of green ICT developments and trends. Another $34.0 \%$ disagreed that they were aware of green ICT developments and trends while $17.9 \%$ fairly disagreed to the same. At least $6.6 \%$ of respondents were neutral in that the respondents were not aware of the trends and developments taking place in green ICT. Awareness aside from being created within formal training may also be done through reading about the area or through workshops and seminars. It can be observed that ICT personnel awareness of trends and developments in green ICT was low and skewed having a standard deviation of 0.93. A good number of the ICT personnel interviewed indicated that they did not fully understand what green ICT was all about. A few confessed that they think green ICT was just but a marketing strategy. With regard to being aware of the trends and development in green ICT by personnel in the case organisation, manufacturing sector having a mean of 2.24 , the communications regulator a mean of 1.91 while the public university sector had a mean of 1.75 and the government office had 1.57.

The findings on the respondents' attendance of seminars and workshops on green ICT are presented in Figure 3 . From the Figures in column 2 a total of $81.3 \%$ of the respondents strongly disagreed that they had attended a green ICT workshop or seminar in the recent past. Another $9.4 \%$ disagreed that they had attended a green ICT workshop or seminar in the recent past while $7.3 \%$ fairly disagreed to the same. At least $2.1 \%$ of respondents were neutral in their response as to whether they had attended a green ICT workshop or seminar in the recent past. ICT personnel's attendance of green ICT seminars / workshops maturity was low and skewed to the left on the Likert scale of 7 . Having a standard deviation of 0.70 is an indication that the respondents were fairly consistent and not spread out suggesting the surety of the view held by ICT personnel. The manufacturing sector had a mean of 1.00 , the communications regulator a mean of 1.38 while the public university sector had a mean of 1.38 and the government office had 1.55 with regard to personnel having attended green ICT seminars / workshops. Very few of the respondents may have had an opportunity to attend green ICT seminars and workshops. This may be due to lack of such seminars and workshops or lack of awareness for the importance and need to do the same arising out of their training.

The ICT personnel formal training in green ICT findings are given in Figure 3. According to column 3 a total of $88.5 \%$ of the respondents indicated strongly that they had no formal training in green ICT. Another $7.3 \%$ disagreed that that they had formal training in green ICT while $4.2 \%$ fairly disagreed to the same. On the overall the ICT personnel have no formal training in green ICT. Training is important in that it is the means by which personnel are equipped with the skills of performing given tasks. The interviews conducted also gave similar results as hardly any of the respondents indicated being in possession of any formal training in green ICT. Having formal training in green ICT had the manufacturing sector having a mean of 1.00 , the communications regulator a mean of 1.05 while the public university sector had a mean of 1.38 and the government office had 1.00 .

The findings as to whether ICT personnel perceived green ICT as simple a marketing strategy instead of an ICT issue to be addressed are provided in Figure 3 . According to column 4 a total of $5.6 \%$ of the respondents strongly disagreed to the fact that green ICT is simply a marketing strategy. Another $35.2 \%$ disagreed that green ICT is simply a marketing strategy while $41.7 \%$ fairly disagreed to the same. At least $12.0 \%$ of respondents were neutral in their response as to 
whether green ICT is simply a marketing strategy. There was a total of $5.6 \%$ of respondents who fairly agreed that green ICT is simply a marketing strategy. In personnel having believe that green ICT was just marketing strategy was the only aspect where the means high which is not good for implementation of green ICT. The manufacturing sector had a mean of 3.29, the communications regulator a mean of 2.05 while the public university sector had a mean of 2.93 and the government office had 2.31. The findings clearly show that respondents do not consider green ICT to be a marketing strategy for organisations. They seem to have an idea of what it is all about.

The study sought to know if there were any respondents who had had some practical experience in implementing green ICT. The findings are presented in Figure 3. According to column 5 a total of $33.3 \%$ of the respondents strongly disagreed to the fact that they had practical experience in implementing green ICT. Another $23.1 \%$ disagreed that they had practical experience in implementing green ICT while $24.1 \%$ fairly disagreed to the same. At least $11.1 \%$ of respondents were neutral in their response as to whether they had practical experience in implementing green ICT. There was a total of $4.6 \%$ of respondents who fairly agreed that they had practical experience in implementing green ICT with another $3.7 \%$ agreeing to the same. Have practical experience in implementing green ICT implementation had the manufacturing sector record a mean of 1.25 , the communications regulator a mean of 1.73 while the public university sector had a mean of 1.57 and the government office had 1.67 .

The means of green ICT professional development maturity was established to be as presented in Figure 4.

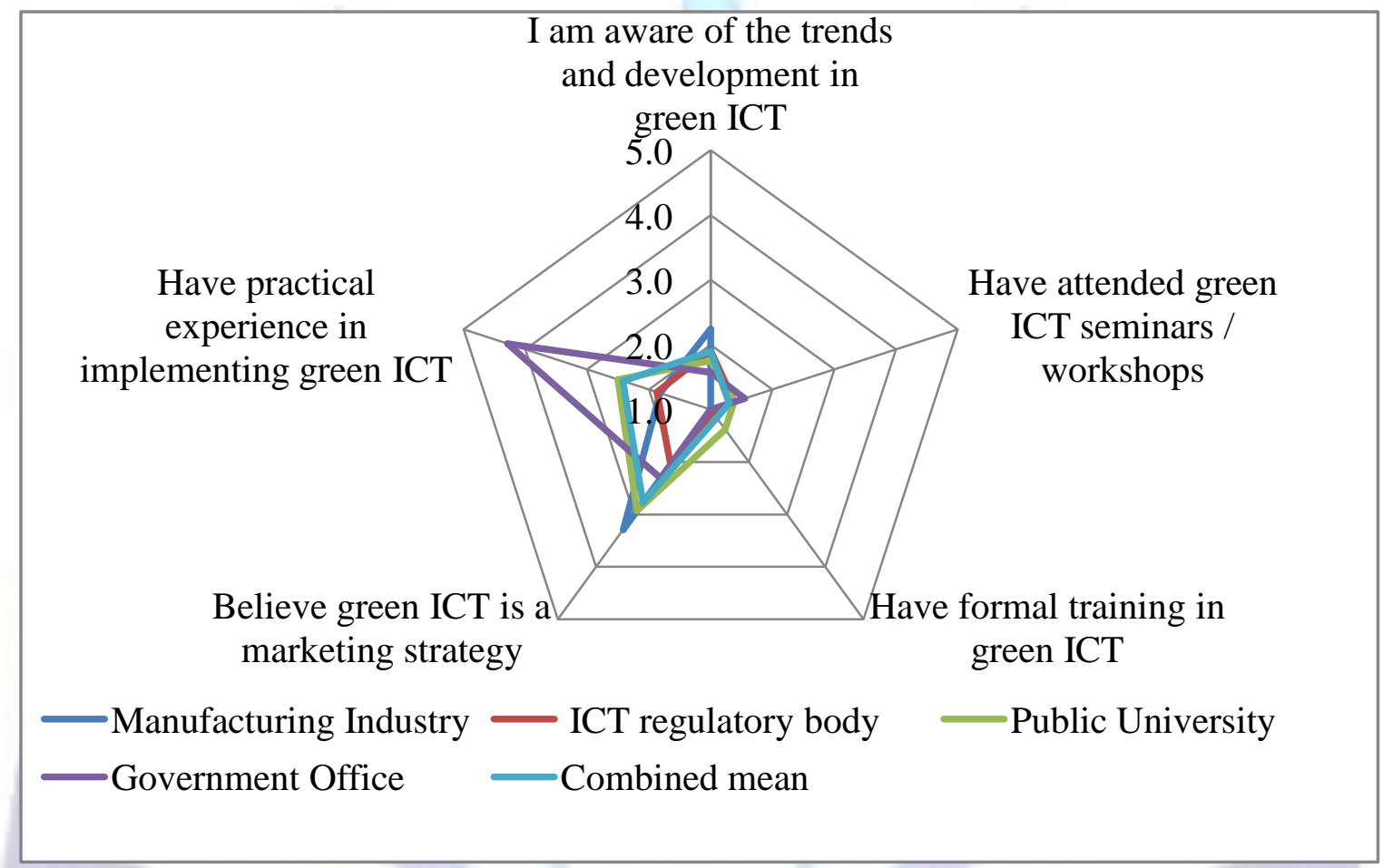

Figure 4: Case study comparison of green ICT professional development maturity

From Figure 4, it can be observed that the green ICT professional development maturity is very low with the curves being very close to one instead of them tending towards seven. It was only the government office where there was some fair mean for having practical experience in implementing green ICT. This may be due to the Governments e-government project that is ongoing.

\subsection{Way forward for ICT personnel G-readiness maturity}

The G-ICT personnel maturity in Kenya was found to be very low. According to the respondents, the maturity was low on green ICT courses being offered in post secondary ICT education programs, existence of green ICT seminars / workshops, skilled green ICT personnel being readily available, budget being set aside for employees to attend green ICT seminars / workshops, scholarships availability for green ICT training and formal qualifications availability in green ICT. When it came to personnel professional maturity it was established that personnel's awareness of trends and development in green ICT, attendance to green ICT seminars / workshops, formal training in green ICT, their believe that green ICT was a marketing strategy for technologies and having had practical experience in implementing green ICT all were very low. Their means revolved around a 1 value that correspondent to strongly disagree to the item being there.

Therefore overall on the green ICT maturity level in the country is low calling for necessary corrective actions to be put in place. 


\subsection{Recommendation}

There is need for deliberate effort to be undertaken towards green ICT education, training and skills development to meet demand for environmental skills and expertise at all levels in Kenya for the benefits of green ICT to be realised. ICT curriculums should be developed that encourage interdisciplinary co-operation in developing green ICT education and training. Use of workshops and seminar on the same may be done to provide an avenue for ICT personnel already in the field to acquire the skills. This would also provide a forum of sharing experiences on the subject within the country. This would make the ICT personnel confident to implement green ICT and push for policies and legislation that would facilitate for its implementation. There is need to engage the available skilled personnel to develop policies to guide the implementation of ICT to actualize the benefits of green ICT.

Funding for further green ICT research, seminars and personnel training may help speed up the attainment of G-personnel readiness maturity

\subsection{Summary and Conclusion}

The paper has discussed G-ICT personnel readiness maturity highlighting its importance towards green ICT. The paper discussed the knowledge gaps that exist in relation to G-ICT personnel. It gave the summary of the methodology used in the study, discussed the findings of the study and finally gave recommendations based on the findings.

Against the background of the findings on personnel maturity towards green ICT implementation, it can be concluded that G-ICT personnel maturity is low in Kenya and hence the need to give it attention. In conclusion, ICT personnel maturity is noted to be crucial for the implementation of green ICT and therefore the need to fully pay attention to it amongst other factors (attitude, policy, practice, technology and governance) proposed by Prof. Molla et al (2009) [3].

\section{ACKNOWLEDGMENTS}

We appreciate the Study financial sponsorship by the National Council of Science Technology and Innovation (Kenya) and the Government of Kenya.

\section{REFERENCES}

[1] Byrd T. A. \& Turner D. E. (2000). Measuring the flexibility of Information Technology Infrastracture: Exploratory Analysis of a Construct. Journal of Management Information Systems, 17 (1): 167-208.

[2] Broadbent M. \& Weil P. (1997). Management by Maxim: How Business and IT Managers can Create IT Infrastractures. Sloan Management Review, Spring, 77-92.

[3] Molla A., Cooper V. A., \& Pittayachawan S. (2009). IT and eco-sustainability: Developing and validating a green IT readiness model. Thirtieth International Conference on Information Systems, (p. 17)

[4] Molla A., Cooper V., Corbitt H., Penszynski K., Pittayachawan S. \& Teoh S. Y. (2008). E-readiness to G-readiness: Developing a Green Information Technology Readiness Framework. Australian Conference on Information Systems 2008 proceedings ACIS-0061-2008. Melbourne: Australia, RMIT University.

[5] Ravichandran T. \& Lertwongsatien C. (2005). Effect of Information Systems Resources and Capabilities on Firm Performance: A resource-based perspective. Journal of Management Information Systems, 21(4), 237-276.

[6] Wabwoba F, Wanyembi W. D, Omuterema S. \& Omieno K. K. (2013). Green ICT Readiness Model for Developing Economies: Case of Kenya International Journal of Advanced Computer Science and Applications (IJACSA), 4(1):5165

[7] Sameni M. K. \& Khoshalhan F. . (July 2006). Analysis of Human Resource Development for Information Technology and E-Commerce in Iran. Tchnology Management for the Global Future (pp. (3) 1186-1202). IEEE: PICMET 2006 (ISBN: 1-890843-14-8).

[8] Cooper V. \& Molla A. (2010). Conceptualizing Green IT Organzational Learning (GITOL). Green IT Working Paper Series. Paper No. 3/2010. Melbourne: School of Business Information Technology and Logistics, RMIT University.

[9] Goulden, B. (2011, march). Managing human capital in the ICT sector in Africa challenges and solutions . Retrieved May 29, 2011, from Pygma Consulting : http://pygmaconsulting.com/Managing\%20Human\%20Capital\%203$11 \% 20$ elec.pdf

[10] Munyua, A. W. (2010). Kenya. In A. Finlay, Global Information Society Watch 2010: Focus on ICTs and Environmental Sustainability (pp. 161-163). APC and HIVOS ISBN 92-95049-96-9.

[11] Enfield J., Myers R. D., Lara M. and Frick T. W. (2011). Innovations diffusion: Assessment of strategies within then diffusion and simulation game. Simulation and gaming, 20 (10): 1-27.

[12] Info-Tech. (2008). Business and Operational Assessment for Virtual Server Implementation. Toronto: Info-Tech research.

[13] Ogunyemi A. A. \& Johnston K. A. (2012). Exploring the roles of people, governance and technology in organizational readiness for emerging technologies. The African Journal of Information Systems, 4 (3): 100-119 
[14] Othman M. F. I., Chan T., Foo E., Nelson K., \& Timbrell G. (2011). Barriers to Information Technology Governance Adoption: A preliminary Emprical Investigation. Proceedings of 15th International Business Information Management Association Conference (pp. 1771-1787). Cairo,Egypt: Queensland University of Technology.

[15] Nfuka E. N, Rusu L, Johannesson P \& Mutagahywa B. (2009). The state of IT governance in organisations from the public sector in developing countries. Proceedings of the 42cd Hawaii International conference on system sciences (HICSS), (pp. 1-12). Hawaii.

[16] King W. R., and Marks Jr P. V. (2008). Motivating knowledge sharing through a knowledge management system. The International Journal of e-collaboration, 36: 131-146.

[17] Apulu I. \& Latham A. (2009). Information and Communication Technology Adoption: Challenges for Nigerian SMEs. TMC Academic Journal, 4(2): 64-80

[18] Castello, P. (2009). Towards a model of ICT adoption for the ICT cluster in the West Midlands. University of Wolverhampton. (PhD Thesis).

[19] Wanyembi, G. (2009). Improving ICT Management in public universities in Kenya. Answers to the problems arising from rapid introduction and use of the new technology. deutschland: VDM Verlag Dr. Muller Aktiengsellschaft \& Co. $\mathrm{Kg}$.

[20] Hedman J. \& Henningsson S. (2011). Three strategies for green IT. IT Professionals: IEEE computer society, 13(1), 54-57.

[21] Herman H., Shalaby B. R., \& Bundgen R. (2010). The greeing of Business. Frankfurt: Am Main: International GmgH.

[22] Niringiye A., Luvanda E. \& Shitundu J. (2010). Human capital and labour productivity in East Africa manifacturing firms. Current research journal of economic theory, 2 (2): 48-54.

[23] Iranzo S, Schivardi F, \& Tosetti E. (2008). Skills despersion and firm productivity: An analysis with employeremployee matched data . Journal of labour economics, 26 (2): 247-285.

[24] Dess G. D. \& Picken J. C. (1999). Beyond productivity: How leading companies achieve superior performance by leveraging their human capital. New York: American Management Association.

[25] Wright P. M. \& McMahan G. C. (1993). Theoretical perspective of human resource management. Journal of management, 18: 295-320.

\section{Author' biography with Photo}

Dr. Franklin Wabwoba is a Senior lecturer at Kibabii University College (Kenya). He holds a PhD (Information

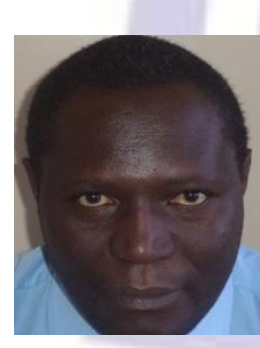
Technology) from Masinde Muliro University of Science and Technology, a Master of Science (Computer Applications) from Kenyatta University; an Endorsement (Educational Management) from University of South Africa, an Advanced Diploma (Human Resource Development) from Institute of Health Care and Administration and a Bachelor of Education (science: Mathematics and Computer Science) degree from Egerton University. He has taught courses in computing disciplines for many years. He has ICT industrial experience having worked with Mumias Sugar Company. He is engaged in several research projects and supervises postgraduate students drawn from a number of universities in Kenya. He is a peer reviewer with a number of international peer reviewed journals. He has published widely in international peer reviewed journals and in scientific conferences proceedings. He has a strong research interest in green ICT, impact of ICT applications on the community, ICT and gender, and integration of ICT into education. He is a professional member of the Association for Computing Machinery (ACM).

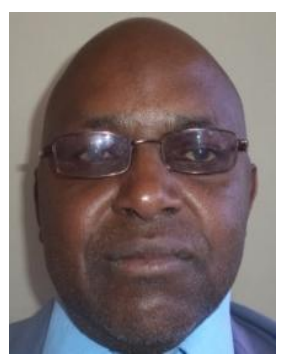

Dr. Samuel M. Mbugua is a lecturer at Kibabii University College. He holds a PhD in Information Technology from Masinde Muliro University of Science and Technology, a Master of Science in Computer Based Information System of University of Sunderland and a Bachelor of Science honours in Electronics Engineering ECE (UK). He has worked in the Broadcast engineering Industry and taught Information and Communication Technology in tertiary institutions, at Diploma, Undergraduates and Graduate levels for many years. He has published widely in international peer reviewed journals and has been a reviewer in the Politics and Policy in the Information Age Book series. He has a strong research interest in Metrics. He is supervising several post graduate students. He is a professional Member of Association for Computing Machinery (ACM) and the British Computer Society (BCS). 


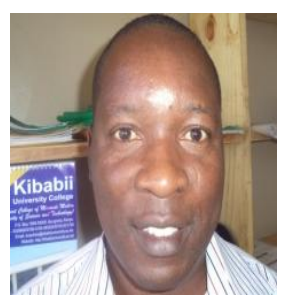

Mr. Anselemo Peters Ikoha reconceived his Bachelor of Education degree from Egerton University, Kenya, and a Master's degree in Computer Based Information Systems from University of Sunderland (UK). He has served as a faculty member in the department of computer science of Masinde Muliro University of science and technology (MMUST). He is currently a PhD (IT) candidate in the department at MMUST and is the chair Department of Computer Science and Information Technology of Kibabii University College. He is a reviewer of articles in a number of international peer reviewed journals. He has also supervised several post-graduate students at masters' level. His research interest covers mobile computing, artificial intelligence systems and Information and communication Technology management and development.

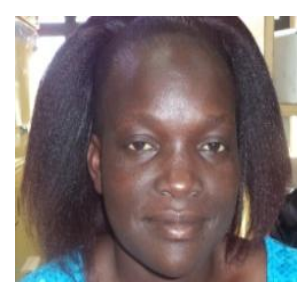

Ms. Dorcus Arshley Shisoka received her Bachelor of Education Science Degree from Egerton University, Kenya, and a Master's Degree in Information Systems Engineering from the University of Sunderland (UK). She is serving as a faculty member in the Department of Computer Science at Kibabii University College. She is a PhD (IT) student at Kibabii University College. Her research interest a

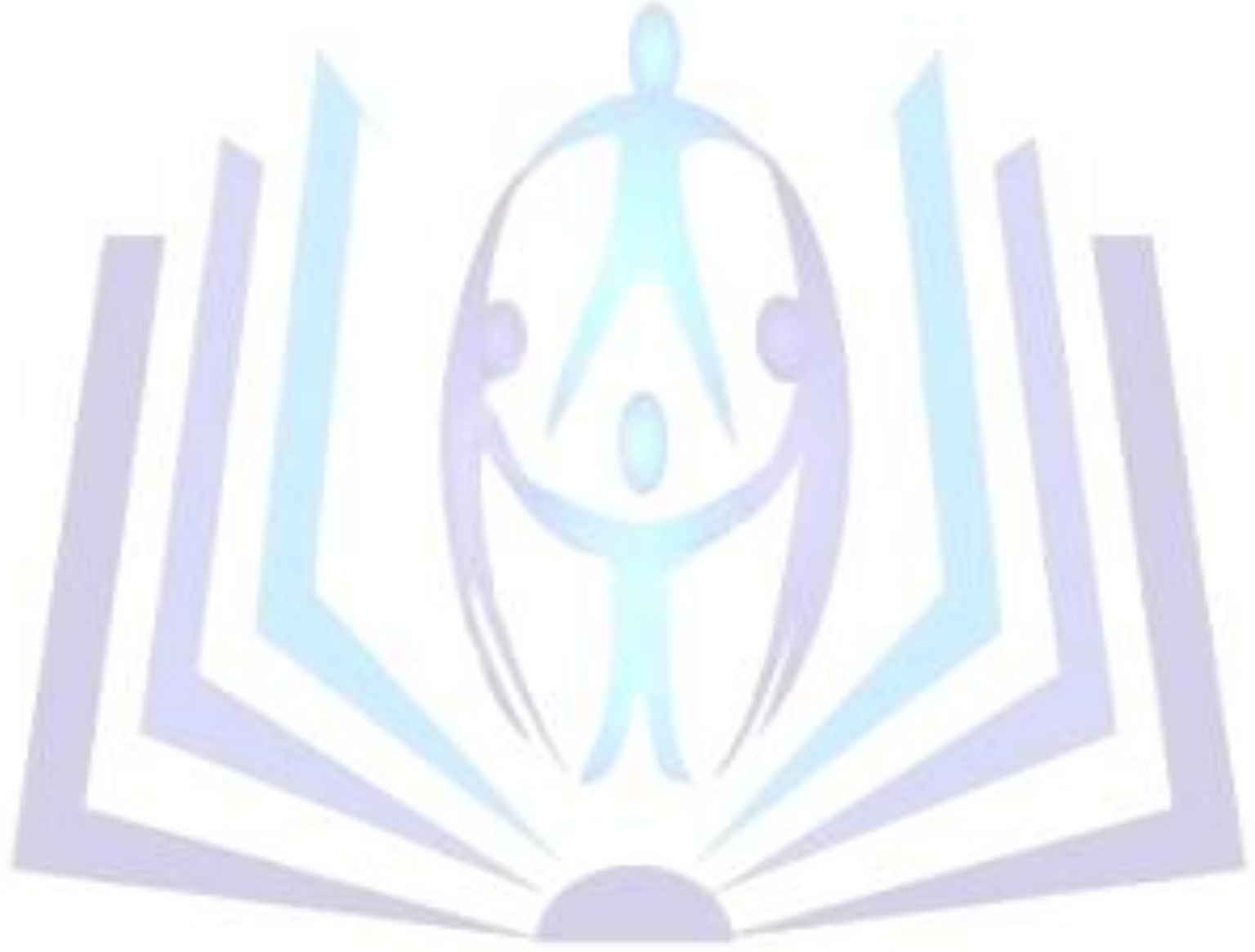

